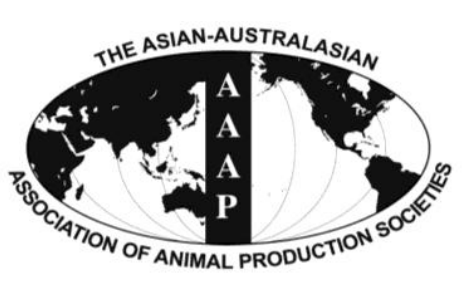

Open Access

Asian Australas. J. Anim. Sci.

Vol. 27, No. 1 : 131-139 January 2014

http://dx.doi.org/10.5713/ajas.2013.13359

www.ajas.info

pISSN 1011-2367 elSSN 1976-5517

\title{
Effect of Dietary Supplementation of Procyanidin on Growth Performance and Immune Response in Pigs
}

\author{
J. C. Park, S. H. Lee, J. K. Hong, J. H. Cho ${ }^{1}$, I. H. Kim ${ }^{1}$, and S. K. Park* \\ National Institute of Animal Science, R.D.A., Suwon 441-706, Korea
}

\begin{abstract}
This study was performed to determine the effect of dietary supplementation of procyanidin on growth performance, blood characteristics, and immune function in growing pigs. In experiment 1 (Exp. 1), thirty-two crossbred pigs with an initial BW of $19.2 \pm 0.3 \mathrm{~kg}$ were allocated into 4 treatments for an 8-wk experiment: i) CON (basal diet), ii) MOS 0.1 (basal diet+0.1\% mannanoligosaccharide), iii) Pro-1 (basal diet+0.01\% procyanidin), and iv) Pro-2 (basal diet+0.02\% procyanidin). Pigs fed Pro- 1 and Pro-2 diets had greater $(\mathrm{p}<0.05)$ gain:feed ratio compared with those fed CON or MOS 0.1 diets. Serum creatinine concentration was less $(\mathrm{p}<0.05)$ in Pro-2 treatment than those in CON, MOS 0.1 and Pro-1 treatments. In Exp. 2, twelve pigs (BW $13.4 \pm 1.3 \mathrm{~kg})$ received basal diet with i) $0(\mathrm{CON})$, ii) $0.02 \%$ (Pro-0.02\%), and iii) $0.04 \%$ procyanidin (Pro-0.04\%) for 4 wk. Concentration of platelets was lower $(\mathrm{p}<0.05)$ in the Pro- $0.04 \%$ group compared to CON at $24 \mathrm{~h}$ after lipopolysaccharide (LPS) challenge. In addition, secretion of cytokines from cultured peripheral blood mononuclear cells (PBMC) in the presence or absence of procyanidin was examined. The levels of interleukin (IL)-1 $\beta$, IL-6 and tumor necrosis factor (TNF)- $\alpha$ were lower $(\mathrm{p}<0.05)$ in Pro (LPS-stimulated PBMCs+procyanidin) than those in CON (LPS-stimulated PBMCs+PBS) at $4 \mathrm{~h}$ after LPS challenge. These data suggest that dietary addition of procyanidin improves feed efficiency and anti-inflammatory cytokines of pigs. (Key Words: Growth Performance, Immune Response, Lipopolysaccharide, Pigs, Procyanidin)
\end{abstract}

\section{INTRODUCTION}

During the past decades, antibiotics have been used as feed additives to improve growth of animals and protect them from pathogenic microorganisms (Meng et al., 2010). However, in recent years, public concerns over the use of antibiotics in livestock have increased due to the emergence of antibiotic-resistant bacteria that may be a hazard to human health (Huang et al., 2010). Therefore, European Union (EU) started to ban the use of antibiotic as feed additives in 1999 and now are considering restricting its use outside EU (Windisch et al., 2008). In Korea, it has been

\footnotetext{
* Corresponding Author: S. K. Park. Animal Nutrition and Physiology Team, National Institute of Animal Science, Suwon 441-706, Korea. Tel: +82-31-290-1657, Fax: +82-31-290-1660, E-mail: maiky@korea.kr

1 Department of Animal Resource and Science, Dankook University, Cheonan, 330-714, Korea.

Submitted May 24, 2013; Accepted Sept. 4, 2013; Revised Oct. 11, 2013
}

required to develop antibiotic-free diets for domestic animals including pigs (Bae et al., 1999). Accordingly, considerable effort has been dedicated to identifying alternatives to antibiotics as growth promoters in the animal industry (Hong et al., 2004; Cho et al., 2006).

Procyanidins have been reported to exert antioxidant properties (Balu et al., 2005; Mohanasundari et al., 2005; Sangeetha et al., 2005; Yahara et al., 2005). They are present in the grape seed extracts and are composed of flavan units linked by $\mathrm{C}_{4}-\mathrm{C}_{6}$ or $\mathrm{C}_{4}-\mathrm{C}_{8}$ bonds forming dimmers, trimers, tetramers, and polymers up to 15 to 16 units (Prieur et al., 1994) with small amounts of catechin and epicatechin (Ricardo da Silva et al., 1990). Flavan compounds possessed many biological effects including scavenging free radicals, chelating transition metals, and modulating activities of antioxidant enzymes. Therefore, they have anti-aging effect, alleviate bone debilities, and protect renal tissues against toxicity. Procyanidins are also known to have therapeutic effects with anti-mutagenic 
(Faria et al., 2006), anti-cytotoxic (Cos et al., 2004), and anti-inflammatory (Selmi et al., 2006) activities. Therefore, this study was performed to determine the effect of oral administration of procyanidin on growth performance and immune response in growing pigs.

\section{MATERIALS AND METHODS}

\section{Preparation of procyanidin}

Procyanidin supplied by SINE-BIO (Seongnam, Korea) was collected and sterilized as described by Hwang et al. (2011). Grape seeds were powdered and soaked in a mixture of acetone/water/acetic acid (v/v/v 70:29.5:0.5). The mixture was filtered and dried under reduced pressure using a rotary evaporator at $40^{\circ} \mathrm{C}$. It was further dried in a vacuum-freeze dryer and $70 \%$ acetone extracts were obtained. Extracts were then separated by $n$-hexane, and separated by an open column chromatography packed with silica gel. The stationary phase was sephadex LH-20 and the mobile phase consisted of a mixture of methanol and water (v/v 20:80). The flow rate was $1.2 \mathrm{~mL} / \mathrm{min}$ and the sample was analyzed at $283 \mathrm{~nm}$ with a spectrometer. The fraction with a retention time of $18.7 \mathrm{~min}$ ( $89 \%$ purity) showed the highest activity and $18 \mathrm{mg}$ of the procyanidin extract was collected from this fraction. Finally, it was dried using a freeze drier. Concentration of extracted procyanidin used in this experiment was mixed with feed at $0.265 \%$.

\section{Animal managements and experimental diets}

The experimental protocols describing the management and care of animals were reviewed and approved by the Animal Care and Use at the National Institute of Animal Science (NIAS). All diets (Table 1) were formulated to meet the nutrient requirements recommended by the official Korean Feeding Standard for Swine (NIAS, 2007). Each pen was provided with a stainless steel feeder and one nipple drinker that allowed for ad libitum access to feed and water throughout the experiment.

\section{Experiment 1: feeding trial}

Experimental design and animals: A total of 32 barrows (Landrace $\times$ Yorkshire) with an average initial BW of $19.2 \pm 0.3 \mathrm{~kg}$ were selected for this $8 \mathrm{wk}$ growth trial. Pigs were allocated to 1 of 4 dietary treatments according to their $\mathrm{BW}$ in a randomized complete block design with 8 pigs per treatment group. Dietary treatments included i) CON (basal diet), ii) MOS 0.1 (basal diet+0.1\% mannanoligosaccharide), iii) Pro-1 (basal diet $+0.01 \%$ procyanidin), and iv) Pro-2 (basal diet $+0.02 \%$ procyanidin).

Growth performance measurements, blood sampling and analysis: Individual pig BW and feed consumption were recorded on $\mathrm{d} 0$ and at the end of the experimental period on d 56 and ADG, ADFI, and gain:feed (G:F) were
Table 1. Composition of diets used in Exp. 1 and Exp. 2 (as-fed basis)

\begin{tabular}{lr}
\hline Item & $\%$ \\
\hline Ingredients & 56.20 \\
Corn & 28.00 \\
Soybean meal & 10.00 \\
Wheat bran & 3.00 \\
Soy oil & 0.10 \\
L-lysine-HCl (78\%) & 0.90 \\
Limestone & 1.00 \\
Calcium phosphate, Dibasic & 0.30 \\
Salt & 0.50 \\
Vitamin-mineral mixture ${ }^{1}$ & 100.00 \\
Total & \\
Chemical composition & 3.40 \\
ME (Mcal/kg) & 19.63 \\
CP $(\%)$ & 1.26 \\
Lysine (\%) & 5.03 \\
Crude fat $(\%)$ & 3.68 \\
Crude fiber $(\%)$ & 4.56 \\
Crude ash (\%) & 0.79 \\
Ca (\%) & 0.58 \\
P (\%)
\end{tabular}

${ }_{1}$ The vitamin-mineral premix provided the following quantities of vitamins and minerals per kilogram of diets: vitamin A, 10,000 IU; vitamin $\mathrm{D}_{3}, 2,000 \mathrm{IU}$; vitamin E, $250 \mathrm{IU}$; vitamin $\mathrm{K}_{3}, 0.5 \mathrm{mg}$; vitamin $\mathrm{B}_{1}$, $0.49 \mathrm{mg}$ as mononitrate; thiamin, $0.49 \mathrm{mg}$ as thiamin mononitrate; riboflavin, $1.50 \mathrm{mg}$; pyridoxine, $1 \mathrm{mg}$ as pyridoxine hydrochloride; vitamin $\mathrm{B}_{12}, 0.01 \mathrm{mg}$; niacin, $10 \mathrm{mg}$ as nicotinic acid; pantothenic acid, 5 $\mathrm{mg}$ as calcium pantothenate; folic acid, $1 \mathrm{mg}$; biotin as d-biotin, $0.1 \mathrm{mg}$; choline, $125 \mathrm{mg}$ as choline chloride; $\mathrm{Mn}, 60 \mathrm{mg}$ as manganese sulfate; $\mathrm{Zn}, 75 \mathrm{mg}$ as zinc sulfate; $\mathrm{Fe}, 20 \mathrm{mg}$ as ferrous sulfate; $\mathrm{Cu}, 3 \mathrm{mg}$ as cupric sulfate; I, $1.25 \mathrm{mg}$ as calcium iodate; $\mathrm{Co}, 0.5 \mathrm{mg}$ as cobaltous carbonate; $\mathrm{Mg}, 10 \mathrm{mg}$ as magnesium oxide.

calculated. Blood samples $(10 \mathrm{~mL})$ were collected via anterior vena cava puncture after the pigs had been starved for $12 \mathrm{~h}$ at the beginning, $3 \mathrm{wk}$, and $8 \mathrm{wk}$ of experimental period. Whole blood sample was centrifuged at $2,000 \times \mathrm{g}$ for $10 \mathrm{~min}$ at $4^{\circ} \mathrm{C}$, and the serum was collected. Serum biochemical profile was determined using a chemistry analyzer (COBAS MIRA plus, ROCHE diagnostics. Block Scientific, Inc. Bohemia, NY, USA).

Superoxide dismutase (SOD) activity: In our study, SOD was measured to investigate the effect of in vivo antioxidant activity of hesperidin. The SOD was determined by the method of Marklund and Marklund (1974). In a cap tube containing $100 \mu \mathrm{L}$ of serum sample (9 wk serum), $1.5 \mathrm{~mL}$ of Tris EDTA $\mathrm{HCl}$ buffer (50 mM Tris, $1 \mathrm{mM}$ EDTA, $6 \mathrm{~N}$ $\mathrm{HCl})$ with $50 \mu \mathrm{L}$ of pyrogallol $(5 \mathrm{mM})$ was incubated at $25^{\circ} \mathrm{C}$ for $30 \mathrm{~min}$. Thereafter, $50 \mu \mathrm{L}$ of $1 \mathrm{~N} \mathrm{HCl}$ was added and vortexed for several seconds. The absorbance of the solution was measured at $420 \mathrm{~nm}$. One unit was the amount of enzyme required to cause $50 \%$ inhibition of pyrogallol oxidation, and SOD activity was expressed as unit/mg 
protein.

\section{Experiment 2: Lipopolysaccharide (LPS) challenge trial}

Experimental design and animals: A total of 12 barrows (Landrace $\times$ Yorkshire) with an average initial $\mathrm{BW}$ of $13.4 \pm 1.3 \mathrm{~kg}$ maintained in individual pens were assigned to 3 dietary treatments in a randomized complete block design based on BW for a 4-wk period. Three treatments included: i) $\mathrm{CON}$ (basal diet), ii) Pro-0.02\% (basal diet $+0.02 \%$ procyanidin), and iii) Pro- $0.04 \%$ (basal diet $+0.04 \%$ procyanidin). The level of procyanidin was increased to $0.04 \%$ since pigs needed to have more procyanidin under LPS challenge to give rise to the effect of procyanidin on pro-inflammatory cytokines. At the end of $4 \mathrm{wk}$, all pigs in each dietary treatment were intraperitoneally injected with Escherichia coli (serotype 0111:B4) LPS (Sigma Chemical Co., St, Louis, MO, USA) at a level of $50 \mu \mathrm{g} / \mathrm{kg}$ of BW. The LPS dosage was referenced on the results of previous studies (Matteri et al., 1998; Wright et al., 2000; Kim et al., 2010).

Blood sampling and measurements: Blood samples (15 $\mathrm{mL}$ ) were collected via anterior vena cava puncture at 0 and $24 \mathrm{~h}$ after LPS injection after the pigs had been starved for $12 \mathrm{~h}$. Blood samples were collected into both nonheparinized tubes $(10 \mathrm{~mL})$ and vacuum tubes $(5 \mathrm{~mL})$ containing $\mathrm{K}_{2}$ EDTA (Becton, Dickinson and Co., Franklin Lakes, NJ, USA) to obtain serum and whole blood, respectively. Blood samples were centrifuged $(2,000 \times \mathrm{g})$ for $10 \mathrm{~min}$ at $4^{\circ} \mathrm{C}$. The white blood cells, red blood cells and platelet concentration in the whole blood were determined using an automatic blood analyzer (Hemavet 950, CDC. Drew Scientific Inc. Dallas, TX, USA). Serum immunoglobulin A (IgA), G (IgG) and $\mathrm{M}$ (IgM) concentrations were evaluated using commercially available ELISA Starter Accessory kits (Bethyl Laboratories, Inc. Montgomery, TX, USA). The absorbance was read at 450 $\mathrm{nm}$ using a microplate reader (Versamax, Molecular Devices, Inc. Sunnyvale, CA, USA).

Peripheral blood mononuclear cells (PBMCs) culture and cytokine secretion: Peripheral blood samples were collected in heparin-containing tubes (Becton, Dickinson and Co., Franklin Lakes, NJ, USA) from 2 healthy piglets that were not used in the experiments. Blood samples were diluted with PBS and layered over a Ficoll-Hypaque (GE Healthcare Bio-Sciences AB. Rapsgatan 7, Uppsala, Sweden) gradient and centrifuged at $2,200 \times \mathrm{g}$ for $17 \mathrm{~min}$ at $10^{\circ} \mathrm{C}$. PBMCs were harvested from the interface layer, washed twice with PBS and then counted. Cells were resuspended in RPMI (Roswell Park Memorial Institute) 1640 GlutaMax (Invitrogen, GIBCO. Carlsbad, CA, USA). Concentration of PBMC was adjusted to $1.25 \times 10^{6}$ viable cells $/ \mathrm{mL}$ after estimation of viability by trypan blue exclusion assay. For the cytokine secretion assay, $200 \mu \mathrm{L}$ of a $1.25 \times 10^{6}$ cell suspension was cultured with an equal volume of flavonoid $25 \mu \mathrm{g} / \mathrm{mL}$ (procyanidin $25 \mu \mathrm{g} / \mathrm{mL}$ ) or PBS. We set the concentration of flavonoids used in this study based on prior dose response analysis conducted by our laboratory (Sanbongi et al., 1997; Mao et al., 1999).

Isolated PBMCs were stimulated with $100 \mathrm{ng} / \mathrm{mL}$ LPS and then cultured in addition of PBS (CON) or procyanidin (Pro) for $2 \mathrm{~h}$ or $4 \mathrm{~h}$ at $38^{\circ} \mathrm{C}$ with $5 \% \mathrm{CO}_{2}$. PBMC interleukin (IL)-1 $\beta$, IL-6 and tumor necrosis factor (TNF)- $\alpha$ concentrations were evaluated using commercially available ELISA kits (Quantikine, R\&D systems, Minneapolis, MN, USA) and the absorbance was measured at $450 \mathrm{~nm}$.

\section{Statistical analysis}

In this experiment, data were analyzed by using GLM procedure of SAS (SAS Institute, 2008). Differences among treatments were analyzed by Duncan's multiple range test (Duncan, 1955). Probability values less than 0.05 were considered significant. Each pen was considered as an experimental unit. In Exp. 2, Cytokine secretion data were analyzed using t-test of SAS (SAS Institute, 2008). Each animal was considered as an experimental unit. Probability values less than 0.05 were considered significant.

\section{RESULTS}

\section{Experiment 1: feeding trial}

Growth performance: During the overall period, no difference was observed in BW, ADG, and ADFI among

Table 2. Effect of dietary supplementation of procyanidin on growth performance in growing pigs (Exp. 1) ${ }^{1}$

\begin{tabular}{lccccc}
\hline \multirow{2}{*}{ Item } & \multicolumn{2}{c}{ Treatment $^{2}$} & \multirow{2}{*}{ SEM } \\
\cline { 2 - 4 } & CON & MOS 0.1 & Pro-1 & Pro-2 \\
Initial BW (kg) & 19.53 & 19.08 & 72.4 & 70.58 & 1.96 \\
Final BW (kg) & 68.9 & 72.18 & 0.85 & 0.81 & 0.02 \\
ADG (kg) & 0.78 & 0.84 & 1.89 & 1.78 & 0.11 \\
ADFI (kg) & 1.95 & 2.12 & $0.425^{\mathrm{a}}$ & $0.458^{\mathrm{a}}$ & 0.012 \\
G:F & $0.381^{\mathrm{b}}$ & $0.380^{\mathrm{b}}$ & & \\
\hline
\end{tabular}

${ }^{1}$ Each least square mean represents 8 observations.

${ }^{2} \mathrm{CON}=$ Basal diet, MOS $0.1=$ Basal diet+mannanoligosaccharide $0.1 \%$, Pro- $1=$ Basal diet + procyanidin $0.01 \%$, Pro- $2=$ Basal diet + procyanidin $0.02 \%$.

${ }^{\mathrm{ab}}$ Means within the same row differ $(\mathrm{p}<0.05)$. 
Table 3. Effects of dietary supplementation of procyanidin on serum biochemical profile in growing pigs (Exp. 1)

\begin{tabular}{|c|c|c|c|c|c|}
\hline & \multicolumn{4}{|c|}{ Treatments $^{2}$} & \multirow{2}{*}{ SEM } \\
\hline & $\mathrm{CON}$ & MOS 0.1 & Pro-1 & Pro-2 & \\
\hline \multicolumn{6}{|c|}{ Creatinine (mg/dL) } \\
\hline 0 week & 1.6 & 1.6 & 1.6 & 1.6 & 0.66 \\
\hline 3 week & $2.2^{\mathrm{a}}$ & $2.1^{\mathrm{a}}$ & $2.1^{\mathrm{a}}$ & $1.5^{\mathrm{b}}$ & 0.13 \\
\hline 8 week & $2.4^{\mathrm{a}}$ & $2.0^{\mathrm{ab}}$ & $2.0^{\mathrm{ab}}$ & $1.9^{\mathrm{b}}$ & 0.08 \\
\hline \multicolumn{6}{|c|}{ Glutamic oxalate transaminase (U/L) } \\
\hline 0 week & 65.9 & 92.3 & 79.3 & 84.4 & 10.77 \\
\hline 3 week & 42.6 & 41.1 & 48.9 & 56.1 & 8.51 \\
\hline 8 week & $28.0^{\mathrm{b}}$ & $62.5^{\mathrm{a}}$ & $38.3^{\mathrm{ab}}$ & $38.8^{\mathrm{ab}}$ & 11.22 \\
\hline \multicolumn{6}{|c|}{ Lactate dehydrogenase (mg/dL) } \\
\hline 0 week & $1,323.8$ & $1,461.5$ & $1,264.0$ & $1,343.0$ & 88.34 \\
\hline 3 week & $624.3^{\mathrm{b}}$ & $913.6^{\mathrm{a}}$ & $1,085.6^{\mathrm{a}}$ & $1,014.6^{\mathrm{a}}$ & 79.40 \\
\hline 8 week & $563.5^{\mathrm{b}}$ & $685.4^{\mathrm{a}}$ & $607.5^{\mathrm{ab}}$ & $585.5^{\mathrm{ab}}$ & 58.84 \\
\hline \multicolumn{6}{|c|}{ Cholesterol (mg/dL) } \\
\hline 0 week & 76.0 & 76.1 & 71.4 & 74.6 & 4.61 \\
\hline 3 week & 70.6 & 79.6 & 65.7 & 66.5 & 4.52 \\
\hline 8 week & 78.6 & 89.1 & 73.8 & 73.4 & 7.17 \\
\hline \multicolumn{6}{|c|}{ Total protein $(\mathrm{g} / \mathrm{dL})$} \\
\hline 0 week & 5.2 & 5.2 & 5.4 & 5.2 & 0.16 \\
\hline 3 week & 6.5 & 5.9 & 6.2 & 5.8 & 0.16 \\
\hline 8 week & 6.1 & 6.4 & 6.4 & 6.3 & 0.12 \\
\hline \multicolumn{6}{|c|}{ Albumin (g/dL) } \\
\hline 0 week & 3.0 & 3.0 & 2.8 & 3.0 & 1.47 \\
\hline 3 week & 3.6 & 3.4 & 3.6 & 3.3 & 0.13 \\
\hline 8 week & 3.7 & 3.9 & 3.8 & 3.8 & 0.08 \\
\hline \multicolumn{6}{|c|}{ Blood urea nitrogen $(\mathrm{mg} / \mathrm{dL})$} \\
\hline 0 week & 23.8 & 24.3 & 19.8 & 23.4 & 1.26 \\
\hline 3 week & 18.9 & 20.6 & 19.7 & 20.9 & 1.80 \\
\hline 8 week & 26.8 & 32.4 & 28.0 & 27.4 & 2.83 \\
\hline
\end{tabular}

${ }^{1}$ Each least squares mean represents 8 observations.

${ }^{2} \mathrm{CON}=$ Basal diet, MOS $0.1=$ Basal diet+mannanoligosaccharide $0.1 \%$, Pro- $1=$ Basal diet + procyanidin $0.01 \%$, Pro- $2=$ Basal diet + procyanidin $0.02 \%$.

${ }^{\mathrm{ab}}$ Means in the same row with different superscripts differ $(\mathrm{p}<0.05)$.

treatments (Table 2). However, dietary Pro-1 (0.425) and Pro-2 (0.458) treatments increased $(\mathrm{p}<0.05) \mathrm{G}: \mathrm{F}$ compared to CON (0.381) or MOS $0.1(0.380)$ group.

Serum biochemical profile: The effects of procyanidin supplementation on serum profile in growing pigs are shown in Table 3. No effects were observed on cholesterol, total protein, albumin and blood urea nitrogen among treatments. However, serum creatinine concentration was significantly lower $(\mathrm{p}<0.05)$ in Pro- 2 treatment than those in CON, MOS 0.1 and Pro- 1 treatments. The glutamic oxalate transaminase concentration was greater $(p<0.05)$ in MOS 0.1 treatment than that in $\mathrm{CON}$ treatment on $8 \mathrm{wk}$. Concentration of lactate dehydrogenase was lower $(p<0.05)$ in CON treatment than all other groups at $3 \mathrm{wk}$.

Superoxide dismutase (SOD) activity: The serum SOD activity in the Pro-2 group was higher $(\mathrm{p}<0.05)$ than that in CON, MOS 0.1 and Pro-1 groups (Table 4).

\section{Experiment 2: LPS challenge trial}

Blood characteristics: White blood cell, red blood cell, hemoglobin, hematocrit, immunoglobulin $\mathrm{A}, \mathrm{G}$, and $\mathrm{M}$ were not influenced by dietary treatments (Table 5). Pigs administrated with Pro- $0.04 \%$ had lower $(\mathrm{p}<0.05)$ platelet concentrations at $24 \mathrm{~h}$ after LPS injection compared to control group.

Table 4. Superoxide dismutase (SOD) activity in serum of pigs (Exp. 1) ${ }^{1}$

\begin{tabular}{|c|c|c|c|c|c|}
\hline & \multicolumn{4}{|c|}{ Treatment $^{2}$} & \multirow{2}{*}{ SEM } \\
\hline & $\mathrm{CON}$ & MOS 0.1 & Pro-1 & Pro-2 & \\
\hline $\begin{array}{l}\text { SOD } \\
\text { (unit/mg protein) }\end{array}$ & $51.23^{b}$ & $51.38^{\mathrm{b}}$ & $51.42^{b}$ & $60.45^{\mathrm{a}}$ & 2.68 \\
\hline $\begin{array}{l}{ }^{1} \text { Each least squares } n \\
{ }^{2} \mathrm{CON}=\text { Basal diet, } \\
\text { Pro- } 1=\text { Basal diet }+ \\
0.02 \% \text {. }\end{array}$ & $\begin{array}{l}\text { an repres } \\
\text { OS } 0.1= \\
\text { ocyanidi }\end{array}$ & $\begin{array}{l}\text { nts } 8 \text { observ } \\
\text { Basal diet }+1 \\
0.01 \% \text {, Pro }\end{array}$ & $\begin{array}{l}\text { itions. } \\
\text { annano } \\
2=\mathrm{Ba}\end{array}$ & $\begin{array}{l}\text { sacc } \\
\text { liet+ }\end{array}$ & $\begin{array}{l}\text { le } 0.1 \% \text {, } \\
\text { cyanidin }\end{array}$ \\
\hline
\end{tabular}


Table 5. Concentrations of white blood cells, red blood cells, platelets and immunoglobulins before and after an immunological challenge with lipopolysaccharide (LPS) following a dietary treatment in growing pigs (Exp. 2) ${ }^{1}$

\begin{tabular}{|c|c|c|c|c|}
\hline \multirow{2}{*}{ Item } & \multicolumn{3}{|c|}{ Treatment $^{2}$} & \multirow{2}{*}{ SEM } \\
\hline & $\mathrm{CON}$ & Pro- $0.02 \%$ & Pro- $0.04 \%$ & \\
\hline \multicolumn{5}{|c|}{ White blood cell $\left(10^{3} / \mu \mathrm{L}\right)$} \\
\hline Before LPS & 17.85 & 16.96 & 13.19 & 2.74 \\
\hline After $24 \mathrm{~h}$ & 16.57 & 16.27 & 16.42 & 1.94 \\
\hline \multicolumn{5}{|c|}{ Red blood cell $\left(10^{6} / \mu \mathrm{L}\right)$} \\
\hline Before LPS & 6.62 & 5.78 & 6.37 & 0.30 \\
\hline After $24 \mathrm{~h}$ & 6.63 & 6.82 & 6.38 & 0.28 \\
\hline \multicolumn{5}{|c|}{ Hemoglobin $(\mathrm{g} / \mathrm{dL})$} \\
\hline Before LPS & 9.77 & 8.17 & 9.13 & 0.47 \\
\hline After $24 \mathrm{~h}$ & 9.03 & 9.22 & 8.63 & 0.58 \\
\hline \multicolumn{5}{|l|}{ Hematocrit (\%) } \\
\hline Before LPS & 29.8 & 25.54 & 28.00 & 1.50 \\
\hline After $24 \mathrm{~h}$ & 30.50 & 32.33 & 28.05 & 1.99 \\
\hline \multicolumn{5}{|c|}{ Platelet $\left(10^{3} / \mu \mathrm{L}\right)$} \\
\hline Before LPS & 406.3 & 412.2 & 295.8 & 76.1 \\
\hline After $24 \mathrm{~h}$ & $487.0^{\mathrm{a}}$ & $385.6^{\mathrm{ab}}$ & $359.0^{\mathrm{b}}$ & 64.3 \\
\hline \multicolumn{5}{|c|}{ Immunogloblin A $(\mathrm{mg} / \mathrm{mL})$} \\
\hline Before LPS & 1.31 & 1.18 & 1.12 & 0.11 \\
\hline After $24 \mathrm{~h}$ & 1.32 & 1.04 & 1.07 & 0.12 \\
\hline \multicolumn{5}{|c|}{ Immunogloblin $\mathrm{G}(\mathrm{mg} / \mathrm{mL})$} \\
\hline Before LPS & 7.4 & 7.58 & 6.21 & 0.93 \\
\hline After $24 \mathrm{~h}$ & 9.81 & 7.33 & 6.97 & 1.25 \\
\hline \multicolumn{5}{|c|}{ Immunogloblin $\mathrm{M}(\mathrm{mg} / \mathrm{mL})$} \\
\hline Before LPS & 1.28 & 1.66 & 1.49 & 0.18 \\
\hline After $24 \mathrm{~h}$ & 1.35 & 1.64 & 1.51 & 0.16 \\
\hline
\end{tabular}

Cytokine secretion following LPS activation: Secretion of IL- $1 \beta$ and TNF- $\alpha$ were lower $(p<0.05)$ in Pro (LPSstimulated PBMCs+procyanidin) treatment than those in CON (LPS-stimulated PBMCs+PBS) treatment at $2 \mathrm{~h}$ and 4 $\mathrm{h}$ after LPS challenge, and IL-6 was lower $(\mathrm{p}<0.05)$ in Pro treatment than in CON treatment at $4 \mathrm{~h}$ after LPS challenge (Table 6).

\section{DISCUSSION}

\section{Experiment 1: feeding trial}

Growth performance: Endotoxin activity of procyanidin was tested by using Lumulus amebocyte lysate (LAL) and no detectable endotoxin was found (Holderness et al., 2007). Procyanidin's endotoxin free property was again tested in various in vivo and in vitro studies including many animals and cell types (Bentivegna, 2002; Yamakoshi et al., 2002; Daughenbaugh et al., 2011; Lluis et al., 2011). Concomitant with these results, pigs treated with very low level of
Table 6. Effects of procyanidin on secretion of pro-inflammatory cytokine by cultured peripheral blood mononuclear cells from piglets following an immunological challenge with lipopolysaccharide in vitro (Exp. 2$)^{1}$

\begin{tabular}{|c|c|c|c|}
\hline \multirow{2}{*}{$\begin{array}{l}\text { Items } \\
(\mathrm{pg} / \mathrm{mL})\end{array}$} & \multicolumn{2}{|c|}{ Treatment $^{2}$} & \multirow{2}{*}{ SEM } \\
\hline & $\mathrm{CON}$ & Pro & \\
\hline \multicolumn{4}{|l|}{ IL-1 $\beta$} \\
\hline $2 \mathrm{~h}$ & $0.64^{\mathrm{b}}$ & $0.20^{\mathrm{a}}$ & 0.05 \\
\hline $4 \mathrm{~h}$ & $1.07^{\mathrm{b}}$ & $0.20^{\mathrm{a}}$ & 0.05 \\
\hline \multicolumn{4}{|l|}{ IL-6 } \\
\hline $2 \mathrm{~h}$ & 60.45 & 61.32 & 10.25 \\
\hline $4 \mathrm{~h}$ & $115.32^{\mathrm{b}}$ & $55.25^{\mathrm{a}}$ & 1.05 \\
\hline \multicolumn{4}{|l|}{ TNF- $\alpha$} \\
\hline $2 \mathrm{~h}$ & $29.83^{\mathrm{b}}$ & $14.57^{\mathrm{a}}$ & 0.65 \\
\hline $4 \mathrm{~h}$ & $103.34^{\mathrm{b}}$ & $14.59^{\mathrm{a}}$ & 1.53 \\
\hline
\end{tabular}

procyanidin, which was compared to those used in toxicity studies, had no sign of harmful effects on health or proinflammatory cytokines.

Discrepancies have been found in the effect of procyanidin on feed intake or growth performance that are fully or partly related to the differences in level of procyanidin in the experimental diets or in animal species used. Supplementation of antioxidant improves growth performance and feed efficiency (Lohakare et al., 2005). Previous studies reported that procyanidin helps reduce stress-related problems and improve growth rate in humans (Wooden et al., 1984; Slayback and Ronald, 2006). Procyanidin also showed these beneficial effects in rabbits (Garcia et al., 2002) and broiler chicks (Brenes et al., 2010). Concomitant with these data, results from the present study showed that administration of procyanidin increased the G:F ratio (Table 2) as well as the antioxidant activity in growing pigs (Table 4). Its beneficial effects on inflammation could reduce energy needs for immune responses thereby maintain animal health and improve growth performance. Therefore, it is possible that procyanidin be used as a feed additive for improving animal health and productivity.

Serum biochemical profile: Blood urea nitrogen (BUN) and serum creatinine (Scr) are well-known indicators of the renal function and health (Chen et al., 2003). However, Scr is a more specific indicator than BUN, since level of BUN can be affected by protein intake and liver function (Mathieson, 2003). Shi et al. (2003) reported that the antioxidant effect of procyanidin is approximately 50 times greater than that of vitamin $\mathrm{C}$ or vitamin E. Procyanidin alleviates the gentamicin induced-kidney injury (Jeong et al., 2005; Han et al., 2008; Hwang et al., 2008; Safa et al., 2010). Animal experiments have also demonstrated that 
procyanidin decreases the Scr concentrations in mice and rats (Kalantari et al., 2007; Yanarates et al., 2008). Concentration of Scr was also decreased by procyanidin treatment in our study (Table 3 ), indicating that procyanidin may have beneficial effects on renal health. However, it will be important to identify the relationship between procyanidin and serum creatinine level and how it helps improve renal function.

Superoxide dismutase (SOD) activity: Superoxide is formed in the red blood cells by auto-oxidation of hemoglobin into methemoglobin (Nordberg and Arnér, 2001). Khan (1999) reported that SOD and glutathione peroxidase (GPX) have roles in an antioxidant defense system. These enzymes are involved in the clearance of superoxide and $\mathrm{H}_{2} \mathrm{O}_{2}$ to maintain the structure and function of biological membranes (McCord, 2000). Oguntibeju et al. (2012) reported that Wistar rats administered with procyanidin $(0.87 \mathrm{mg} / \mathrm{kg} \mathrm{BW})$ showed increased SOD level compared to controls. Dietary supplementation of procyanidin also improved $(\mathrm{p}<0.05)$ the SOD-like activity in growing pigs from the present study (Table 4). This result is consistent with our hypothesis that supplementation of procyanidin may result in an increase in plasma flavanol level and an increase in the antioxidant capacity of plasma.

\section{Experiment 2: LPS challenge trial}

Blood characteristics: As a constituent of gramnegative bacteria cell walls, LPS induces the expression of many genes necessary for immune defense function (Tracey et al., 1994). Therefore, it is plausible to detect the inhibitory effect of procyanidin on the expression of inflammatory cytokines with a LPS challenge. Consequently, the present results confirm its ability to inhibit the production of multiple cytokines and thereby improve anti-inflammatory effect in pigs. Procyanidin has positive effects on the platelet concentration after LPS challenge (Zhang et al., 2006; Martinez-Micaelo et al., 2012). Zhang et al. (2009) reported that LPS promotes platelet activity by inducing the secretion of both $\alpha$ and dense granules, thus amplifying secretion-dependent platelet aggregation. Previous studies showed that platelets are involved in the pathogenesis of severe sepsis (Taylor et al., 1997; Pu et al., 2001; Zhao et al., 2002), and that LPS stimulates thrombosis, the formation of platelet microaggregates (Rumbaut et al., 2006).

Procyanidins are polymeric compounds derived from catechin and epicatechin (Pasinetti et al., 2010). They modulate platelet function, thus reduced the risk of clot formation (Karen et al., 2003). Pignatelli et al. (2000) suggested that procyanidin decreases platelet production induced by hydrogen peroxide. Procyanidin interferes oxidation process, decreases platelet activation and increases eicosanoid synthesis (Karen et al., 2003). These responses result in lowering the platelet activation, thereby decreases the concentration of platelets. Procyanidin also increases concentration of plasma prostacyclin. Prostacyclin decreases platelet aggregation in vivo and ex vivo by elevating platelet cyclic AMP concentration and inhibiting agonist-induced increase in glycoprotein IIb-IIa expression and phosphorylation. Administration of procyanidin inhibits platelet aggregation in rats (Chang and Hsu, 1989; Ruf et al., 1995), dogs (Demrow et al., 1995) and humans (Rein et al., 2000; Freedman et al., 2001). Concomitant with these results, pigs administrated with Pro- $0.04 \%$ treatment also showed lower $(\mathrm{p}<0.05)$ platelet concentration compared to control group in this study (Table 5), suggesting that administration of procyanidin derived from catechin and epicatechin inhibits platelet aggregation in LPS-challenged pigs.

Cytokine Secretion Following LPS Activation: Inflammation and acute phase responses after LPS challenge have been well characterized in a pig model (Johnson, 1997; Wright et al., 2000). Several proinflammatory cytokines, such as TNF- $\alpha$, IL-6, and IL-1, are encoded by target genes in the $\mathrm{NF}_{\mathrm{k}} \mathrm{B}$ activation pathway (Yang et al., 2008). $\mathrm{NF}_{\mathrm{k}} \mathrm{B}$ acts as a crucial transcriptional activator of pro-inflammatory cytokines and its expression is triggered by pro-inflammatory stimuli and genotoxic stress, including bacterial cell-wall components (Karin and Greten, 2005).

IL-1 $\beta$, a pro-inflammatory cytokine, is a mediator of LPS toxicity in vivo and in vitro (Lee, 2007). Mao et al. (2005) reported that IL-1 $\beta$ level was increased by LPS, but pigs fed Astragalus membranaceus $\beta$-glucan (AMG) had a lower level of IL-1 $\beta$ than pigs from control group when they were challenged with LPS. TNF- $\alpha$ is produced at early onset of inflammation followed by waves of IL-1 and IL-6 (Tizard, 2000). However, TNF- $\alpha$ causes a detrimental effect on animal performance by compromising immunity and nutrient metabolism (Spurlock, 1997). These results may highlight the important role of these cytokines in regulation of immune and inflammatory responses. Procyanidin decreases the expression of IL- 6 and TNF- $\alpha$ (Mackenzie et al., 2004; Erlejman et al., 2008; Terra et al., 2009). The potent anti-inflammatory property of procyanidin has been shown in rats and mice (Li et al., 2001; Sakaguchi et al., 2006). In this study, we assessed serum concentration of cytokines in association with dietary administration of procyanidin with experimentally imposed stimulation of the immune system by LPS. As expected, procyanidin decreased LPS-induced IL-1 $\beta$, IL- 6 and TNF- $\alpha$ production in PBMCs. Our results indicate that procyanidin may have the potential to suppress the inflammatory response and be effective for ameliorating the bacteria challenged antiinflammatory response in pigs. 


\section{CONCLUSION}

Taken together, dietary supplementation of procyanidin may help prevent over-stimulation of the immune system in growing pigs after an immunological challenge. In addition, procyanidin improves feed efficiency and decreases the serum creatinine concentrations in pigs. Further research, however, is necessary to identify the specific mechanisms by which procyanidin improves immune function and growth performance in growing pigs.

\section{ACKNOWLEDGEMENTS}

This work was carried out with the support of "cooperative research program for Agriculture Science \& Technology Development (Project No. PJ009340)”, Rural Development Administration, Republic of Korea.

\section{REFERENCES}

Bae, K. H., T. G. Ko, J. H. Kim, W. T. Cho, Y. K. Han, and I. K. Han. 1999. Use of metabolically active substances to substitute for antibiotics in finishing pigs. Korean J. Anim. Sci. 41:23-30.

Balu, M., P. Sageetja, D. Haripriya, and C. Panneerselvam. 2005. Rejuvenation of antioxidant system in central nervous system of aged rats by grape seed extract. Neurosci. Lett. 383:295-300.

Bentivegna, S. S. and K. M. Whitney. 2002. Subchronic 3-month oral toxicity study of grape seed and grape skin extracts. Food Chem. Toxicol. 40:1731-1743.

Brenes, A., A. Viveros, I. Goni, C. Centeno, F. Saura-Calixto, and I. Arija. 2010. Effect of grape seed extract on growth performance, protein and polyphenol digestibilities, and antioxidant activity in chickens. Span. J. Agric. Res. 8:326-333.

Chang, W. C. and F. L. Hsu. 1989. Inhibition of platelet aggregation and arachidonate metabolism in platelets by procyanidins. Prostaglandins Leukot. Essent. Fatty Acids 38:181-1888.

Chen, S. T., S. J. Peng, and J. R. Chen. 2003. Effects of dietary protein on renal function and lipid metabolism in five-sixths nephrectomized rats. Br. J. Nutr. 89:491-497.

Cho, J. H., Y. J. Chen, B. J. Min, H. J. Kim, O. S. Kwon, K. S. Shon, I. H. Kim, S. J. Kim, and A. Asamer. 2006. Effects of essential oils supplementation on growth performance, IgG concentration and fecal noxious gas concentration of weaned pigs. Asian-Aust. J. Anim. Sci. 19:80-85.

Cos, P., T. de Bruyne, N. Hermans, S. Apers, D. V. Berghe, and A. J. Vlietinck. 2004. Proanthocyanidins in health care: Current and new trend. Curr. Med. Chem. 11:1345-1359.

Daughenbaugh, K. F., J. Holderness, J. C. Graff, J. F. Hedges, B. Freedman, J. W. Graff, and M. A. Jutila. 2011. Contribution of transcript stability to a conserved procyanidin-induced cytokine response in $\gamma \delta \mathrm{T}$ cells. Genes Immun. 12:378-389.

Demrow, H. S., P. R. Slane, and J. D. Folts. 1995. Administration of wine and grape juice inhibits in vivo platelet activity and thrombosis in stenosed canine coronary arteries. Circulation 91:1182-1188.
Duncan, D. B. 1955. Multiple range and multiple $\mathrm{F}$ tests. Biometrics 11:1-42.

Erlejman, A. G., G. Jaggers, C. G. Fraga, and P. I. Oteiza. 2008. $\mathrm{TNF} \alpha$-induced $\mathrm{NF}_{-\mathrm{k}} \mathrm{B}$ activation and cell oxidant production are modulated by hezameric procyanidins in Caco- 2 cells. Arch. Biochem. Biophys. 476:186-195.

Faria, A., C. Calhau, V. de Freitas, and N. Mateus. 2006. Procyanidins as antioxidants and tumor cell growth modulators. J. Agric. Food Chem. 54:2392-2397.

Freedman, J. E., C. III. Parker, L. Li, J. A. Perlman, B. Frei, V. Ivanov, L. R. Deak, M. D. Iafrati, and J. D. Folts. 2001. Select flavonoids and whole juice from purple grapes inhibit platlet function and enhance nitric oxide release. Circulation 103:2792-2798.

Garcia, J., N. Nicodemus, R. Carabano and J. C. de Blass. 2002. Effect of inclusion of defated grape seed meal in the diet on digestion and performance of growing rabbits. J. Anim. Sci. 80:162-170.

Han, J. Y., J. H. Sung, D. J. Kim, H. S. Jeong, and J. S. Lee. 2008. Inhibitory effect of methanol extract and its fractions from grape seeds on mushroom tyrosinase. J. Korean Soc. Food Sci. Nutr. 37:1679-1683.

Holderness, J., L. Jackiw, E. Kimmel, H. Kerns, M. Radke, J. F. Hedges, C. Petrie, P. McCurley, P. M. Glee, A. Palecanda, and M. A. Jutila. 2007. Select plant tannins induce IL-2R upregulation and augment cell division in $\gamma \delta \mathrm{T}$ cells. J. Immunol. 179:6468-6478.

Hong, J. W., I. H. Kim, O. S. Kwon, B. J. Min, W. B. Lee, and K. S. Shon. 2004. Influences of plant extract supplementation on performance and blood characteristics in weaned pigs. AsianAust. J. Anim. Sci. 17:374-378

Huang, Y., J. S. Yoo, H. J. Kim, Y. Wang, Y. J. Chen, J. H. Cho, and I. H. Kim. 2010. Effects of dietary supplementation with blended essential oils on growth performance, nutrient digestibility, blood profiles and fecal characteristics in weanling pigs. Asian-Aust. J. Anim. Sci. 23:607-613.

Hwang, D. S., S. Y. Shin, Y. G. Lee, J. Y. Hyun, Y. J. Yong, J. C. Park, Y. H. Lee, and Y. H. Lim. 2011. A compound isolated from Schisandra chinensis induces apoptosis. Bioorg. Med. Chem. Lett. 21:6054-6057.

Hwang, I. W., H. R. Lee, S. K. Kim, H. Z. Zheng, J. U. Choi, S. H. Lee, S. H. Lee, and S. K. Chung. 2008. Proanthocyanidin content and antioxidant characteristics of grape seeds. Korean J. Food Preserv. 15:859-863.

Jeong, S. M., S. Y. Kim, J. U. Ha, and S. C. Lee. 2005. Effect of far-infrared irradiation on the antioxidant activity of extracts from grape seed. J. Korean Soc. Food Sci. Nutr. 34:1619-1624.

Johnson, R. W. 1997. Inhibition of growth by pro-inflammatory cytokines: An integrated view. J. Anim. Sci. 75:1244-1255.

Kalantari, H., I. Rashidi, S. Bazgir, and A. Dibaei. 2007. Protective effects of hydroalcoholic extract of red grape seed (VITIS VENIFERA) in nephrotoxicity induced by amikacin in mice. Jund. J. Nat. Parm. Products 2:87-93.

Karen, J. K., K. C. Andriana, S. Indu, A. F. Maureen, M. Helen, J. P. Marilyn, H. T. Alan, J. M. Neil, and J. S. Andrew. 2003. Dietary flavanols and procyanidin oligomers from cocoa (Theobroma cacao) inhibit platelet function. Am. J. Clin. Nutr. 77:1466-1473. 
Karin, M. and F. R. Greten. 2005. $\mathrm{NF}_{\mathrm{k}} \mathrm{B}$ : Linking inflammation and immunity to cancer development and progression. Nat. Rev. Immunol. 5:749-759.

Khan, M. A. 1999. Chemical composition and medicinal properties of Nigella sativa Linn. Inflammopharmacology 7:15-35.

Kim, B. G., M. D. Lindemann, and G. L. Cromwell. 2010. The effects of dietary chromium (III) picolinate on growth performance, vital signs, and blood measurements of pigs during immune stress. Biol. Trace Elem. Res. 135:200-210.

Lee, E. 2007. Anti-inflammatory effect of Scutellariae Radix. Korean J. Pant. Res. 20:548-552.

Li, W. G., X. Y. Zhang, Y. J. Wu, and X. Tian. 2001. Antiinflammatory effect and mechanism of proanthocyanidins from grape seeds. Acta. Pharmacol. Sin. 22:1117-1120.

Lluis, L., M. Munoz, M. R. Nogues, V. S. Martos, M. Romeu, M. Giralt, J. Valls, and R. Sola. 2011. Toxicology evaluation of a procyanidin-rich extract from grape skins and seeds. Food Chem. Toxicol. 49:1450-1454.

Lohakare, J. D., M. H. Ryu, T. W. Hahn, J. K. Lee, and B. J. Chae. 2005. Effects of supplemental ascorbic acid on the performance and immunity of commercial broilers. J. Appl. Poult. Res. 14:10-19.

Mackenzie, G. G., F. Carrasquedo, J. M. Delfino, C. L. Keen, C. G. Fraga, and P. I. Oteiza. 2004. Epicatechin, catechin, and dimeric procyanidins inhibit PMA-induced $\mathrm{NF}_{-\mathrm{k}} \mathrm{B}$ activation at multiple steps in Jurkat T cells. FASEB J. 18:167-169.

Mao, T. K., J. J. Powell, J. van de Water, C. L. Keen, H. H. Schmitz, and M. E. Gershwin. 1999. The influence of cococa procyanidins on the transcription of interleukin-2 in peripheral blood mononuclear cells. Int. J. Immunother. 15:23-29.

Mao, X. F., X. S. Piao, C. H. Lai, D. F. Li, J. J. Xing, and B. L. Shi. 2005. Effect of $\beta$-glucan obtained from the chinese herb Astragalus membranaceus and lipopolysaccharide challenge on performance, immunological, adrenal, and somatotropic responses of weanling pigs. J. Anim. Sci. 83:2775-2782.

Marklund, S. and G. Marklund. 1974. Involvement of the superoxide anion radical in the autoxidation of pyrogallol and a convenient assay for superoxide dismutase. Eur. J. Biochem. 47:469-474.

Martinez-Micaelo, N., N. González-Abuín, X. Terra, C. Richart, A. Ardèvol, M. Pinent, and M. Blay. 2012. Omega-3 docosahexaenoic acid and procyanidins inhibit cyclooxygenase activity and attenuate NF-kB activation through a p105/p50 regulatory mechanism in macrophage inflammation. Biochem. J. 441:653-663.

Mathieson, P. W. 2003. Immune dysregulation in minimal change nephropathy. Nephrol. Dial. Transplant. 6:26-29.

Matteri, R. L., J. J. Klir, B. N. Fink, and R. W. Johnson. 1998. Neuroendocrine-immune interactions in the neonate. Domest. Anim. Endocrinol. 15:397-407.

McCord, J. M. 2000. The evolution of free radicals and oxidative stress. Am. J. Med. 108:652-659.

Meng, Q. W., L. Yan, X. Ao, H. D. Jang, J. H. Cho, and I. H. Kim. 2010. Effects of chito-oligosaccharide supplementation on egg production, nutrient digestibility, egg quality and blood profiles in laying hens. Asian-Aust. J. Anim. Sci. 23:14761481.

Mohanasundari, M., M. Sabesan, and S. Sethupathy. 2005.
Renoprotective effect of grape seeds extract in ethylene glycol induced nephrotoxic mice. Indian J. Exp. Biol. 43:356-359.

National Institute of Animal Science (NIAS). 2007. Korean feeding standard for Swine, Korea.

Nordberg, J. and E. S. Arnér. 2001. Reactive oxygen species, antioxidants, and the mammalian thioredoxin system. Free Radic. Biol. Med. 31:1287-1312.

Oguntibeju, O. O., A. N. Fashola, and C. L. Cole-Showers. 2012. Effects of procyanidin on antioxidant enzyme status in kidney and heart homogenates of Wistar rats. J. Food Agric. Environ. 10:34-37.

Pasinetti, G. M., H. Ksiezak-Reding, I. Santa-Maria, J. Wang, and L. Ho. 2010. Development of grape seed polyphenolic extract with anti-oligomeric activity as a novel treatment in progressive supranuclear palsy and other tauopathies. J. Neurochem. 114:1557-1568.

Pignatelli, P., F. M. Pulcinelli, A. Celestini, L. Lenti, A. Ghiselli, P. P. Gazzaniga, and F. Violi. 2000. The flavonoids quercetin and catechin synergistically inhibit platelet function by antagonizing the intracellular production of hydrogen peroxidase. Am. J. Clin. Nutr. 72:1150-1155.

Prieur, C., J. Rigaud, V. Cheyner, and M. Moutounet. 1994. Oligomeric and polymeric procyanidin from grape seed. Phytochemistry 36:781-784.

$\mathrm{Pu}$, Q., E. Wiel, D. Corseaux, R. Bordet, M. A. Azrin, M. D. Ezekowitz, N. Lund, B. Jude, and B. Vallet. 2001. Beneficial effect of glycoprotein IIb/IIIa inhibitor (AZ-1) on endothelium in Escherichia coli endotoxin-induced shock. Crit. Care Med. 29:1181-1188.

Rein, D., T. G. Paglieroni, D. A. Pearson, T. Wun, H. H. Schmitz, R. Gosselin, and C. L. Keen. 2000. Cocoa and wine polyphenols modulate platelet activation and function. J. Nutr. 130:2120S-2126S.

Ruf, J. C., J. L. Berger, and S. Renaud. 1995. Platelet rebound effect of alcohol withdrawal and wine drinking in rats. Relation to tannins and lipid peroxidation. Arterioscler. Thromb. Vasc. Biol. 15:140-144.

Rumbaut, R. E., R. V. Bellera, J. K. Randhawa, C. N. Shrimpton, S. K. Dasgupta, J. F. Dong, and A. R. Burns. 2006. Endotoxin enhaces microvascular thrombosis in mouse cremaster venules via a TKR4-dependent, neutrophil-independent mechanism. Am. J. Physiol. Heart Circ. Physiol. 290:H1671-1679.

Ricardo da Silva, J. M., J. P. Rosec, M. Bourzeix, and N. Heredia. 1990. Separation and quantitative determination of grape and wine procyanidins by high performance reversed phase liquid chromatography. J. Sci. Food Agric. 53:85-92.

Sanbongi, C., N. Sizuki, and T. Sakane. 1997. Polyphenols in chocolate, which have antioxidant activity, modulate immune function in humans in vitro. Cell. Immunol. 177:129-136.

SAS Institute. 2008. SAS user's guide, Statistical Analysis System Inst. Inc Cary NC.

Safa, J., H. Argani, B. Bastani, N. Nezami, B. Rahimi Ardebili, A. Ghorbanihaghjo, H. Kalagheichi, A. Amirfirouzi, M. Mesgari, and J. Soleimany Rad. 2010. Protective effect of grape seed extract on gentamicin-induced acute kidney injury. Iran. J. Kidney Dis. 4:285-291.

Sakaguchi, Y., H. Shirahase, K. Kunishiro, A. Ichikawa, M. Kanda, and Y. Uehara. 2006. Effect of combination of nitric oxide synthase and cyclooxygenase inhibitors on carrageenan- 
induced pleurisy in rats. Life Sci. 79:442-447.

Sangeetha, P., M. Balu, D. Haripriya, and C. Panneerselvam. 2005. Age associated change in erythrocyte membrane surface charge: Modulatory role of grape seed proanthocyanidin. Exp. Gerontol. 40:820-828.

Selmi, C., T. K. Mao, C. L. Keen, H. H. Schmitz, and M. Eric Gershwin. 2006. The anti-inflammatory properties of cocoa flavanols. J. Cardiovasc. Pharmacol. 47:S163-S171.

Shi, J., J. Yu, J. E. Pohorly, and Y. Kakuda. 2003. Polyphenolics in grape seeds-biochemistry and functionality. J. Med. Food 6:291-299.

Slayback, L. D. and R. W. Ronald. 2006. Bioflavonoids and cardiovascular health: tea, red wine, cocoa and pycnogenol ${ }^{\circledR}$. J. Am. Nutrac. Assoc. 9:16-21.

Spurlock, M. E. 1997. Regulation of metabolism and growth during immune challenge: an overview of cytokine function. J. Anim. Sci. 75:1773-1783.

Taylor, F. B., B. S. Coller, A. C. Chang, G. Peer, R. Jordan, W. Engellener, and C. T. Esmon. 1997. 7E3 F(ab')2, a monoclonal antibody to the platelet GPIIb/IIIa receptor, protects against microangiopathic hemolytic anemia and microvascular thrombotic renal failure in baboons treated with $\mathrm{C} 4 \mathrm{~b}$ binding protein and a sublethal infusion of Escherichia coli. Blood 89: 4078-4084.

Terra, X., G. Montagut, M. Bustos, N. Llopiz, A. Ardèvol, C. Bladé, J. Fernández-Larrea, G. Pujadas, J. Salvadó, L. Arola, and M. Blay. 2009. Grape-seed procyanidins prevent lowgrade inflammation by modulating cytokine expression in rats fed a high-fat diet. J. Nutr. Biochem. 20:210-218.

Tizard, I. R. 2000. Veterinary immunology: An introduction. W.B. Sauders Company. Philadelphia, PA.

Tracey, K. J., A. Cerami. 1994. Tumor Necrosis Factor: A pleiotropic cytokine and therapeutic target. Annu. Rev. Med. 45:491-503.

Windisch, W. M., K. Schedle, C. Plitzner, and A. Kroismayr. 2008. Use of phytogenic products as feed additives for swine and poultry. J. Anim. Sci. 86:E140-148.
Wooden, G. R., C. S. Crane, and C. G. Beisel. 1984. An investigation of the effect of hesperidin complex and lemon bioflavonoid complex on growth and development of thoroughbred horses. J. Anim. Sci. 59:1529-1535.

Wright, K. J., R. Balaji, C. M. Hill, S. S. Dritz, E. L. Knoppel, and J. E. Minton. 2000. Integrated adrenal, somatotropic, and immune responses of growing pigs to treatment with lipopolysaccharide. J. Anim. Sci. 78:1892-1899.

Yahara, N., I. Tofani, K. Maki, K. Kojima, Y. Kijima, and M. Kimura. 2005. Mechanical assessment of effects of grape seed proanthocyanidins extract on tibial bone diaphysis in rats. J. Musculoskelet Neuronal Interact 5:162-169.

Yamakoshi, J., M. Saito, S. Kataoka, and M. Kikuchi. 2002. Safety evaluation of proanthocyanidin-rich extract from grape seeds. Food Chem. Toxicol. 40:599-607.

Yanarates, O., A. Guven, A. Sizlan, B. Uysal, O. Akgul, A. Atim, A. Ozcan, A. Korkmaz, and E. Kurt. 2008. Ameliorative effects of proanthocyanidin on renal ischemia/reperfusion injury. Ren. Fail. 30:931-938.

Yang, X., Y. Guo, X. He, J. Yuan, Y. Yang, and Z. Wang. 2008. Growth performance and immune responses in chickens after challenge with lipopolysaccharide and modulation by dietary different oils. Animal 2:216-223.

Zhang, G., J. Han, E. J. Welch, R. D. Ye, T. A. VoynoYasenetskaya, A. B. Malik, X. Du, and Z. Li. 2009. Lipopolysaccharide stimulates platelet secretion and potentiates platelet aggregation via TLR4/MyD88 and the cGMP-dependent protein kinase pathway. J. Immunol. 182:7997-8004.

Zhang, W. Y., H. Q. Liu, K. Q. Xie, L. L. Yin, Y. Li, C. L. KwikUribe, and X. Z. Zhu. 2006. Procyanidin dimer B2 [epicatechin-(4 $\beta-8)$-epicatechin] suppresses the expression of cyclooxygenase-2 in endotoxin-treated monocytic cells. Biochem. Biophys. Res. Commun. 345:508-515.

Zhao, L., Y. Ohtaki, K. Yamaguchi, M. Matsushita, T. Fujita, T. Yokochi, H. Takada, and Y. Endo. 2002. LPS-induced platelet response and rapid shock in mice: contribution of O-antigen region of LPS and involvement of the lectin pathway of the complement system. Blood 100:3233-3239. 